\title{
THE EFFECT OF A CATION EXCHANGE RESIN ON ELECTROLYTE BALANCE AND ITS USE IN EDEMATOUS STATES
}

\author{
BY LESLIE IRWIN, EUGENE Y. BERGER, BENJAMIN ROSENBERG, AND \\ ROSLYN JACKENTHAL \\ (From the Third New York University Research and Medical Services, Goldwater Memorial \\ Hospital, Welfare Island, New York, N. Y.)
}

(Received for publication April 25, 1949)

In ancient Greece, "terra sigillata" or "sealed earth" was reputed to be a successful counter agent for poisons (1). Its fame grew through the centuries commensurately with the refined custom of poisoning one's dinner partner.

Early trials of the effectiveness of "terra sigillata" are reported in two 16th century documents (2). The first, dated 1580 , records that of eight dogs who were fed various poisons, including mercury sublimate, the four that received "terra sigillata" survived, while the others died. A 1581 account details another successful experiment in which the "earth" was administered to a condemned criminal immediately following "a dram and a half of Mercurie Sublimate."

"Terra sigillata" was found, in 1914, to consist of oxides of calcium and aluminum with a large proportion of silicates (2). Thompson, the analyst, attributed "its virtues ... chiefly due to the mystery surrounding its origin and the superstitions connected with its source." In the light of more recent knowledge, however, the action of "terra sigillata" may well be explained on the physico-chemical grounds of an ion exchange.

Ion exchangers are insoluble substances which remove ions from solution by releasing one ion in exchange for another (3-6). Way, in 1850, first observed the phenomenon of ion exchange in soil (7). Subsequently a number of naturally occurring substances were found to have cation exchange properties but were of limited use because of their low exchange capacity and chemical instability (8, 9). Advances over the naturally occurring substances were the development of "zeolites" from sodium aluminate and sodium silicate (10-13), and of synthetic organic exchangers from sulfonated coals (14). In 1934, Adams and Holmes prepared synthetic phenol-formaldehyde resins with cation exchange properties and introduced resins prepared from aromatic amines and formal- dehyde which were capable of exchanging anions (15).

In 1945 anion exchange resins, which remove such ions as chloride, sulfate, and phosphate from solution, were utilized in the therapy of peptic ulcer (16-18). The next year Dock suggested that cation exchange resins, which remove such ions as sodium, potassium, calcium, and magnesium from solution, be used to take up sodium from ingested food. He showed that the particular resin he used was non-toxic in dogs and rats when fed in massive doses over a two-week period (19).

The present study concerns observations of electrolyte interchange between a cation exchange resin and medium, in vitro and in vivo. The resin was also evaluated in the therapy of congestive heart failure and cirrhosis of the liver by comparing measures needed to control accumulation of fluid with and without resin. The resin used was Liquonex CRW ${ }^{1}$ passed through a 120 mesh screen. The insoluble cation exchange resin is a sulfonated polystyrene capable of neutralizing from 3.9 to $4.5 \mathrm{mEq}$. of base per gram of resin.

\section{PROCEDURES}

In vitro: Solutions of known composition were mixed with the resin and the surrounding fluid analyzed in order to determine the proportions of various ions removed under a variety of circumstances.

In vivo: A constant diet was fed to a subject and the effect of oral administration of resin on his electrolyte balance was observed. The subject, a 59 year old male, had neither history nor sign of cardiac or renal dysfunction although he had a mild systolic hypertension and a right hemiparesis. He was cooperative enough to consume the following three meals daily for 80 days. Breakfast consisted of tomato juice, two eggs, a slice of bread with a pat of butter and a glass of milk. Dinner and supper consisted of two ounces of ham, a potato, one

1 The authors are indebted to Dr. Sidney Sussman (Liquid Conditioning Corp., Linden, N. J.) for the preparation and supply of this resin. Liquonex CRW is essentially Dowex 50 . 
slice of bread with a pat of butter, a glass of milk and grapefruit. On analysis the diet was found to contain $112 \mathrm{mEq}$. of sodium, $87 \mathrm{mEq}$. of potassium, $47 \mathrm{mEq}$. of calcium, $118 \mathrm{mEq}$. of chloride, $44 \mathrm{mM}$ of inorganic phosphorus, and 11.9 grams of nitrogen (75 grams of protein). Water was allowed ad libitum.

After a period of 20 days on the diet an amount of resin was administered each day equivalent to $100 \mathrm{mEq}$. of base. One-third of the daily dose of resin was ingested in plain gelatin capsules during each meal. After nine days the dose was increased to $150 \mathrm{mEq}$. Twelve days later the dose was increased to $200 \mathrm{mEq}$. and then in eight days to $250 \mathrm{mEq}$. After six days on $250 \mathrm{mEq}$. the resin was discontinued and the patient was observed for an additional 25 days.

The subject was weighed daily. Twenty-four hour urines were collected under oil using toluene as a perservative. The urinary specific gravity, volume, creatinine, $\mathrm{pH}$ and titratable acid, total nitrogen, ammonia, sodium, potassium, calcium, inorganic phosphorus, sulfate and chloride were determined. The feces were collected in three-day periods, dried under an infra-red lamp, weighed and ground to a fine powder in a mortar and analyzed for total nitrogen (less ammonia nitrogen), inorganic phosphorus and chloride. Aliquots of the dried feces were treated with concentrated sulfuric acid, ashed overnight at $800^{\circ} \mathrm{C}$ and analyzed for sodium, potassium and calcium. At 10-day intervals determinations were made of the plasma sodium, potassium, calcium, phosphorus, carbon dioxide combining power, chlorides, $\mathrm{pH}$, urea nitrogen and alkaline phosphatase.

Urinary specific gravity was determined with a urinometer. Urinary $\mathrm{pH}$ was determined under oil and the urine was then titrated to $\mathrm{pH} 7.4$ with $0.02 \mathrm{~N}$ sodium hydroxide. Sodium and potassium were determined with an internal standard flame photometer (20). Calcium was measured by dissolving the precipitated oxalate in $2 \mathrm{~N}$ sulfuric acid and adding an excess of hexanitratoammonium cerate. The cerate was back titrated with ferrous ammonium sulfate using ortho-phenanthroline ferrous sulfate as an indicator. Chloride was determined according to Wilson and Ball (21) ; phosphorus accord-

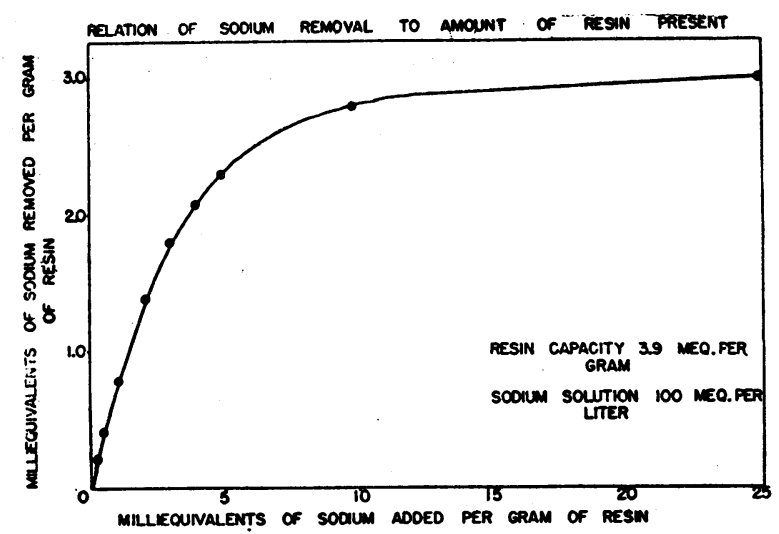

FIG. 1

ing to Fiske and Subbarow (22) ; ammonia and urea according to Summerson's modification of the Van Slyke and Cullen procedure (23); creatinine by a modification of the Folin method (24). Sulfate was determined by a turbidimetric method using barium chloride (25). Total nitrogen was determined by the micro-Kjeldahl technique. Phosphatase was determined by the King and Armstrong method (26).

\section{OBSERVATIONS}

\section{In Vitro}

Liquonex CRW like other hydrogen exchange resins removes sodium from solution by forming an insoluble combination of sodium and resin, releasing a free hydrogen ion for each sodium ion fixed to the resin.

As the amount of sodium added per gram of resin was increased, more sodium was removed per gram until the resin was saturated (Figure 1). The volume of water in which the sodium was dissolved had little effect on sodium removal by the

TABLE I

The removal of calcium, potassium and sodium from solution by Liquonex $C R W$

\begin{tabular}{|c|c|c|c|c|c|c|c|c|c|}
\hline \multicolumn{4}{|c|}{ Solution } & \multicolumn{3}{|c|}{ mEq. added per gram of resin* } & \multicolumn{3}{|c|}{$\begin{array}{l}\text { Per cent of added ion removed } \\
\text { from solution }\end{array}$} \\
\hline Medium & $\mathrm{Ca}$ & $\mathbf{K}$ & $\mathrm{Na}$ & $\mathrm{Ca}$ & $\mathbf{K}$ & $\mathrm{Na}$ & $\mathrm{Ca}$ & $\mathbf{K}$ & $\mathrm{Na}$ \\
\hline $\begin{array}{l}\text { Water } \\
\text { 0.93N } \mathrm{HCl} \\
0.3 \mathrm{~N} \mathrm{NaOH} \\
\text { Water } \\
\text { Water } \\
\text { Milk pH } 5.0 \\
\text { Milk pH } 6.8 \\
\text { Milk pH } 7.5 \\
\text { Water }\end{array}$ & $\begin{array}{c}m E q . / L \\
26 \\
26 \\
26 \\
15 \\
250 \\
13 \\
18 \\
19 \\
5\end{array}$ & $\begin{array}{c}m E q . / L \\
29 \\
29 \\
29 \\
40 \\
389 \\
41 \\
41 \\
39 \\
5\end{array}$ & $\begin{array}{c}m E q . / L \\
30 \\
31 \\
31 \\
55 \\
552 \\
51 \\
54 \\
57 \\
140\end{array}$ & $\begin{array}{l}m E q . \\
0.69 \\
0.71 \\
0.69 \\
0.41 \\
0.75 \\
0.36 \\
0.49 \\
0.51 \\
0.08\end{array}$ & $\begin{array}{l}m E q . \\
0.79 \\
0.79 \\
0.79 \\
1.07 \\
1.29 \\
1.10 \\
1.09 \\
1.04 \\
0.07\end{array}$ & $\begin{array}{l}m E q . \\
0.81 \\
0.83 \\
0.84 \\
1.47 \\
1.84 \\
1.38 \\
1.46 \\
1.53 \\
2.05\end{array}$ & $\begin{array}{c}\text { per cent } \\
100 \\
100 \\
100 \\
98 \\
92 \\
96 \\
94 \\
92 \\
100\end{array}$ & $\begin{array}{c}\text { per cent } \\
86 \\
77 \\
91 \\
81 \\
74 \\
81 \\
82 \\
82 \\
86\end{array}$ & $\begin{array}{c}\text { per cent } \\
43 \\
19 \\
58 \\
44 \\
29 \\
43 \\
54 \\
59 \\
64\end{array}$ \\
\hline
\end{tabular}

* Resin capacity $3.9 \mathrm{mEq}$. of base per gram 
resin. Studies of combinations of sodium and resin which would approximate the ratio encountered in the intestine revealed the resin to be incompletely saturated with sodium. Therefore, if the amount of salt is increased in a diet containing a constant amount of resin, a goodly proportion of the increment will be fixed to the resin.

Ions of higher valence or higher molecular weight tend to occupy the resin in preference to ions of lower valence or lower molecular weight (Table I) (27). The resin had a greater affinity for potassium and calcium than for sodium regardless of the medium in which these ions were dissolved. The capacity to remove cation was enhanced in alkaline solution. Sodium, potassium, and calcium in solution in the proportions present in the diet did not affect the preferential removal of potassium and calcium over sodium.

Sodium and potassium chloride were added to milk to approximate the proportions of sodium, potassium, and calcium in the diet. The $\mathrm{pH}$ of this solution was 6.8. Ultrafiltration by a Sims ultrafilter revealed 56 per cent of the calcium to be bound to protein. The same solution was also studied after the $\mathrm{pH}$ had been'adjusted to 5.0 with dilute acid and to 7.5 with dilute alkali.: None of these manipulations affected the affinity of the resin for potassium and calcium over sodium. Calcium bound to the protein left the protein to occupy space on the resin.

Using a solution in which the ratio of ions was such as is found in the fluid of the ileum (140 $\mathrm{mEq}$. of sodium, $5 \mathrm{mEq}$. of potassium, and $5 \mathrm{mEq}$. of calcium), 64 per cent of added sodium was removed. In this instance, $1.32 \mathrm{mEq}$. of sodium were removed per gram of resin whereas the maximum amount of sodium removed per gram of resin in the other combinations was $0.8 \mathrm{mEq}$. per gram. This is a result of the higher ratio of sodium to calcium and potassium.

The action of a cation exchange substance is not limited to inorganic cations alone but basic organic materials adhere as well. When a solution containing $123 \mathrm{mg}$. of nitrogen as glycine, a relatively neutral amino acid, was added to a gram of resin, 50 per cent of the glycine was fixed to the resin. Likewise, when $157 \mathrm{mg}$. of nitrogen as a mixture of amino acids in solution (Amigen) were added to a gram of resin, 31 per cent of the amino acids was fixed to the resin. It must be recognized that this type of experiment does not indicate the firmness of the bond between the amino acid and the resin.

\section{In Vivo}

These observations of the action of the resin suggested the alterations in electrolyte balance that might be anticipated in vivo. The actual alterations were measured following resin administration to a human subject.

The subject remained well and symptomless throughout the period of resin administration except for the last day when he was nauseated. $\mathrm{He}$ fully recovered in 24 hours. During the 80 days of resin administration the subject lost $3.6 \mathrm{~kg}$. of weight which he regained by the ninth day after resin was discontinued. The mean urinary volume was greater during resin administration $(2110 \mathrm{ml}$.) than during the control period (1640 ml.). The larger volume of urine excreted is for the most part accounted for by the extra water necessary to help swallow the capsules.

Urinary excretion of sodium averaged $109 \mathrm{mEq}$. per day during the control period. As the daily dose of resin was increased from 106 to $250 \mathrm{mEq}$. urinary sodium excretion fell to $10 \mathrm{mEq}$. per day (Figure 2). There were certain vagaries in urinary sodium excretion that corresponded with

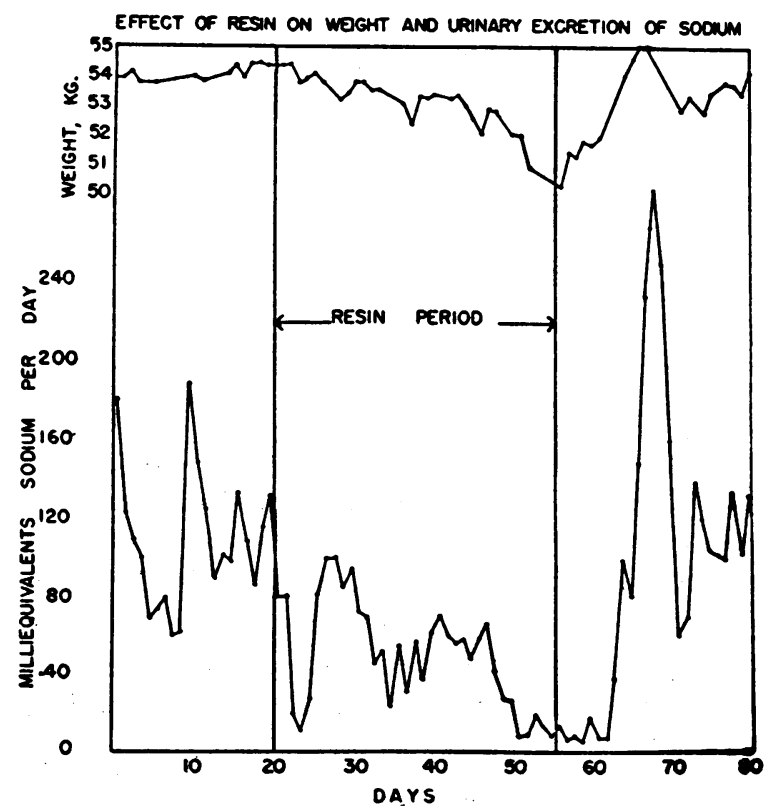

FIg. 2 
TABLE II

Changes in plasma constituents during resin administration

\begin{tabular}{|c|c|c|c|c|c|c|c|c|c|c|}
\hline Day & Period & Sodium & Potassium & Chloride & $\begin{array}{l}\text { Carbon } \\
\text { dioxide* }\end{array}$ & $\mathrm{pH}$ & Calcium & Phosphate & $\begin{array}{l}\text { Alkaline } \\
\text { phosph. }\end{array}$ & $\underset{\text { nitrogen }}{\text { Urea }}$ \\
\hline $\begin{array}{r}4 \\
16 \\
20\end{array}$ & $\begin{array}{l}\text { Control } \\
\text { Control } \\
\text { Resin Introduced }\end{array}$ & $\begin{array}{c}m E q . / L \\
140.0 \\
140.0\end{array}$ & $\begin{array}{l}m E q . / L \\
4.68 \\
4.16\end{array}$ & $\begin{array}{c}m E q . / L \\
102.8 \\
101.0\end{array}$ & $\begin{array}{l}m M / L \\
27 \\
32.4\end{array}$ & $\begin{array}{l}\text { units } \\
7.35 \\
7.45\end{array}$ & $\begin{array}{l}m E q . / L \\
4.2 \\
5.9\end{array}$ & $\begin{array}{l}m M / L \\
1.37 \\
0.88\end{array}$ & $\begin{array}{c}K-A \text { units } \\
4.6 \\
8.6\end{array}$ & $\begin{array}{c}\text { mg. per cen } \\
14.9 \\
9.0\end{array}$ \\
\hline $\begin{array}{l}28 \\
37 \\
46 \\
53 \\
55\end{array}$ & $\begin{array}{l}\text { Resin } \\
\text { Resin } \\
\text { Resin } \\
\text { Resin } \\
\text { Resin Discontinued }\end{array}$ & $\begin{array}{l}144 . \\
137.2 \\
140.8 \\
135.3\end{array}$ & $\begin{array}{l}3.63 \\
3.61 \\
4.20 \\
2.65\end{array}$ & $\begin{array}{l}104.5 \\
101.0 \\
108.0 \\
112.0\end{array}$ & $\begin{array}{l}27.4 \\
25.2 \\
21.3 \\
18.9\end{array}$ & $\begin{array}{l}7.45 \\
7.38 \\
7.45\end{array}$ & $\begin{array}{l}5.8 \\
5.3 \\
5.15 \\
4.9\end{array}$ & $\begin{array}{l}0.98 \\
0.88 \\
0.95 \\
0.92\end{array}$ & $\begin{array}{l}3.0 \\
6.8 \\
4.4\end{array}$ & $\begin{array}{l}16.8 \\
13.2 \\
13.5 \\
13.7\end{array}$ \\
\hline $\begin{array}{l}56 \\
63 \\
74\end{array}$ & $\begin{array}{l}\text { Post Resin } \\
\text { Post Resin } \\
\text { Post Resin }\end{array}$ & $\begin{array}{l}141.2 \\
139.4\end{array}$ & $\begin{array}{l}3.34 \\
4.03\end{array}$ & $\begin{array}{l}109.0 \\
100.0 \\
104.0\end{array}$ & $\begin{array}{l}22.5 \\
28.8\end{array}$ & $\begin{array}{l}7.40 \\
7.45\end{array}$ & $\begin{array}{l}4.7 \\
4.4\end{array}$ & $\begin{array}{l}0.88 \\
0.82\end{array}$ & 3.8 & $\begin{array}{r}8.4 \\
16.0\end{array}$ \\
\hline
\end{tabular}

* Combining power

weight changes, the explanation of which is not clear. For ten days after the discontinuance of resin, it remained low ( $10 \mathrm{mEq}$. per day) and was then followed by a profuse diuresis of $325 \mathrm{mEq}$. per day before returning approximately to the level of the dietary intake. Plasma sodium did not vary appreciably during the study (Table II).

The patient experienced constipation towards the end of the resin period. This accounts for the low fecal excretion of sodium and potassium at this time (Figures 3 and 5). The feces for 13

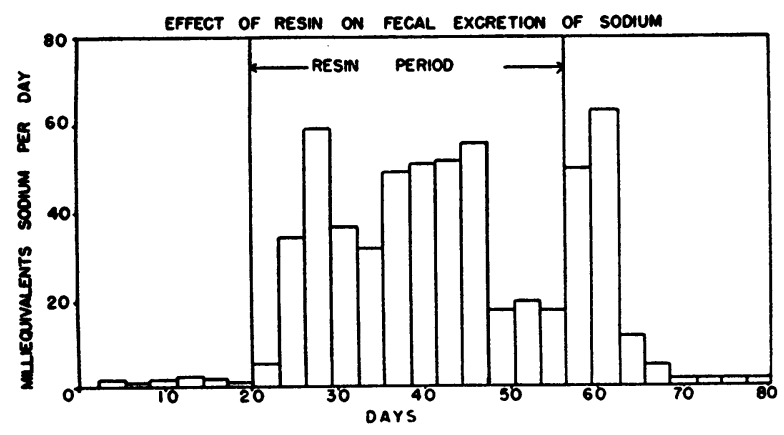

FIG. 3

days after the resin was discontinued contained normal amounts of nitrogen while the weight indicated that resin was still present. Consequently, feces excreted in these 13 days may be considered as part of the resin period. On this basis, the mean fecal excretion of sodium increased from $1.4 \mathrm{mEq}$. per day during the control to $51.0 \mathrm{mEq}$. per day during the resin period. ${ }^{2}$ At the time the patient

${ }^{2}$ Liquonex CRW itself contains a small amount of sodium and the fecal excretion of sodium has been accordingly corrected. was receiving 200 to $250 \mathrm{mEq}$. of resin per day, the fecal sodium representative of this period was about 80 per cent of the dietary sodium (Figure 3).

Urinary potassium excretion did not show the fluctuations that occurred in the urinary sodium excretion (Figure 4). From a mean control value of $78.5 \mathrm{mEq}$. per day it fell over a period of 30 days to a level of $7 \mathrm{mEq}$. per day as the dosage of resin increased. After the discontinuance of the resin the potassium excretion also remained at a low level for 10 days before it rose to equal the dietary intake. Plasma potassium remained relatively stable except for one value of $2.6 \mathrm{mEq}$. per liter toward the end of resin administration. Mean daily fecal potassium excretion increased from $5.8 \mathrm{mEq}$. during the control to $58.6 \mathrm{mEq}$. during resin feeding (calculated similarly to the sodium). Fecal potassium during resin administration was thus 68 per cent of the dietary potassium.

Mean daily urinary calcium excretion was 13 $\mathrm{mEq}$. during the control period, $8.8 \mathrm{mEq}$. during resin administration and $11.2 \mathrm{mEq}$. in the postresin period. The mean daily fecal calcium excretion was $40 \mathrm{mEq}$. during the control period and

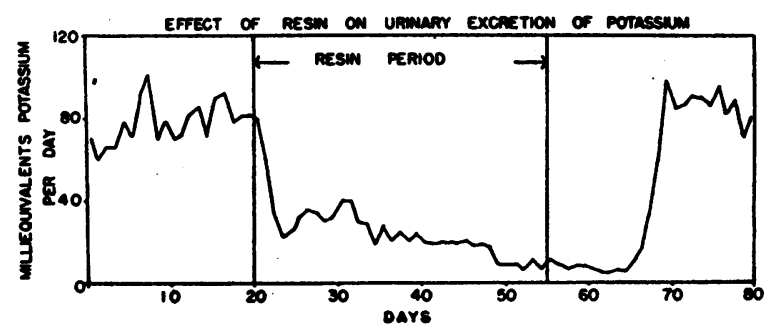

FIG. 4 


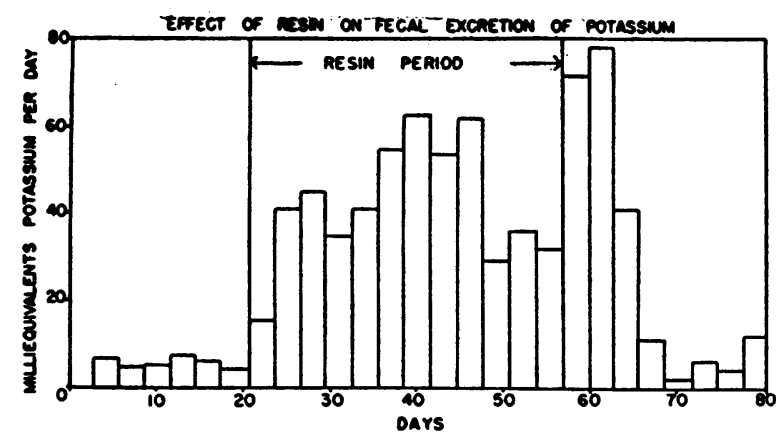

FIG. 5

$35.1 \mathrm{mEq}$. during resin administration (Figure 6 ). Statistically the mean daily excretion of urinary or fecal calcium did not differ among these periods. There were no appreciable changes in plasma calcium or alkaline phosphatase.

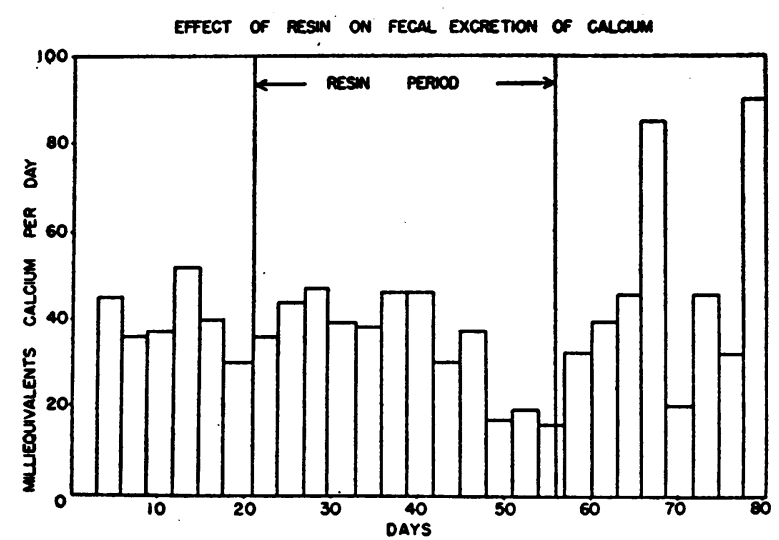

FIg. 6

During the control and resin periods dietary sodium, potassium and calcium compared well with the urinary plus fecal output of these ions. Balance studies thus failed to indicate loss of sodium, potassium or calcium from the body.

The mean daily urinary excretion of chloride, phosphate, and sulfate were not appreciably different in the control, resin and post-resin periods. They were respectively 124,110 and $121 \mathrm{mEq}$. for chloride; 27.5, 29.7 and $22 \mathrm{mM}$ for phosphate; and 32.3, 37.0, and $38.6 \mathrm{mEq}$. for sulfate. There were no appreciable changes in the fecal excretion of chloride or phosphorus. Plasma phosphorus was not altered.

The reduced absorption of sodium and potassium from the gut in the presence of a relatively constant absorption of chloride, phosphate. and sulfate illustrates the mechanism of the acidosis induced by the resin. As resin administration progressed, plasma carbon dioxide combining power fell from 27 to $19 \mathrm{mM}$ per liter and the chloride rose from 102 to $112 \mathrm{mEq}$. per liter with no significant change in $\mathrm{pH}$ of blood (Table II). This exemplifies the compensated metabolic acidosis described by Gamble (28).

The kidney balanced the excess chloride, phosphate and sulfate relative to sodium and potassium by formation of ammonia (Figure 7). Ammonia production increased from a mean value of 25 $\mathrm{mEq}$. per day during the control period to 211 $\mathrm{mEq}$. per day on the 34th day of resin administration. The mean urinary $\mathrm{pH}$ during the control periods was 6.3 and during resin feeding was 6.0. The mean daily titratable acidity increased from $17.2 \mathrm{mEq}$. during the control period to $25.6 \mathrm{mEq}$. during the resin period. It may be seen that the shift in $\mathrm{pH}$ did not contribute greatly to balance the anion excess. It is of interest that additional calcium was not excreted in the urine to help balance this anion excess.

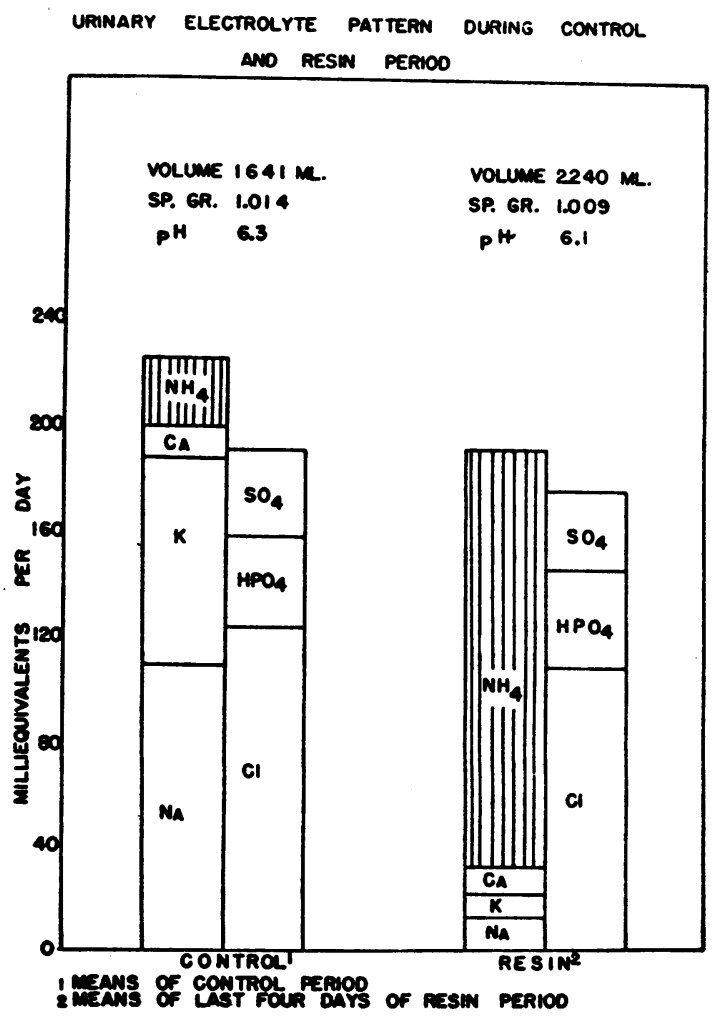

FIG. 7 
The mean daily excretion of urinary nitrogen for control and resin periods was 10.2 and 10.5 grams respectively. In the first 10 days following discontinuance of the resin, urinary excretion of nitrogen fell to a daily mean of 8.8 grams following which the mean was 10.5 grams. The mean daily fecal nitrogen was $0.68,0.68$, and 0.61 grams for the control, resin and post-resin periods respectively. Except for the 10 days immediately after discontinuance of the resin, where there was a retention of nitrogen, total nitrogen intake of 11.9 grams compared well with total output. There was no consistent change in blood urea nitrogen.

\section{Clinical Application}

Two pertinent effects were noted in the administration of resin to this subject. Sodium was immobilized in the gut and a compensated metabolic acidosis was produced. These two situations would be acceptable in the therapy of edematous states. The resin was therefore tested for its usefulness in the therapy of two cases of congested heart failure and one case of cirrhosis of the liver with ascites and edema.

The patient A. C. was a 62 year old male with luetic heart disease and aortic insufficiency. He was observed for six weeks on a regular diet containing approximately 6 grams of salt. Moderate compensation was maintained with three $2 \mathrm{ml}$. injections of mercuhydrin each week plus 0.1 gram of digitalis daily. At the end of this sixweek period mercurials were discontinued but the diet and digitalis were maintained. The patient was begun on gradually increasing doses of resin starting at 100 mEq. daily. After a slight weight gain during the first four days, his weight stabilized for the succeeding four days, whereupon he began to lose weight. As the dosage of resin was increased to $270 \mathrm{mEq}$. daily over a 16-day period, there was a $2.5 \mathrm{~kg}$. weight loss. The resin was discontinued and he promptly gained $4.6 \mathrm{~kg}$. in 10 days. The resin was again instituted and the patient lost 2.7 kg. in five days.

The patient C. G. was a 55 year old white female with rheumatic heart disease. During a control period of 37 days on an acid ash diet containing 3 grams of sodium chloride, she required 0.1 gram and $0.2 \mathrm{gram}$ of digitalis every other day and $2 \mathrm{ml}$. mercupurin about every five days. Her greatest weight during this period was 46.9 kg., her lowest was $41.4 \mathrm{~kg}$. With institution of resin in daily dosage of $230 \mathrm{mEq}$., diet was changed to one containing 6 grams of salt daily, mercupurin was discontinued, digitalis dosage was maintained. The patient's weight fell from $46.9 \mathrm{~kg}$. to $42.2 \mathrm{~kg}$. in 12 days. At this time the patient vomited. Digitalis toxicity was considered to be the cause and both digitalis and resin were discontinued. Serum carbon dioxide combining power was normal. Digitalis was resumed after five days in daily dosage of 0.1 gram and the resin was resumed after 10 days. During the 10 days without the resin her weight increased from $42.2 \mathrm{~kg}$. to $47.3 \mathrm{~kg}$. With daily dosage of 150 to $200 \mathrm{mEq}$. of resin, she maintained a weight of $45.5 \mathrm{~kg}$. over a 40 -day period without requiring mercupurin. Plasma carbon dioxide combining power and plasma potassium were not altered in this period. When the resin was discontinued she gained $2 \mathrm{~kg}$. in four days and experienced a return of paroxysmal nocturnal dyspnea.

The patient J. O. was a 52 year old white male with symptoms of decompensated cirrhosis of the liver with abdominal ascites and peripheral edema. During a sevenweek observation period in the hospital, he accumulated fluid at a rate which required mercupurin every 10 days. His greatest weight was $59.4 \mathrm{~kg}$., and his lowest, $56.0 \mathrm{~kg}$. following mercupurin. With the institution of resin in dosage of $100 \mathrm{mEq}$. per day, his weight fell from 57.4 to $53.5 \mathrm{~kg}$. in 12 days. The patient maintained his appetite fairly well during these 12 days but with the loss of edema fluid, cachexia became apparent. At this time plasma carbon dioxide content had fallen from 24.5 to $13.8 \mathrm{mM}$ per liter, plasma chloride rose from 101 to $110 \mathrm{mEq}$. per liter and potassium rose from -2.9 to 5.9 mEq. per liter. Oral administration of the resin, however, was continued for another 10 days. There was a further weight loss to $49.5 \mathrm{~kg}$. at which point ascites could not be detected clinically. The patient became anorexic. Plasma carbon dioxide content fell to $8.5 \mathrm{mM}$ per liter, chloride rose to $114 \mathrm{mEq}$. per liter, potassium was $2.3 \mathrm{mEq}$. per liter. The resin was discontinued and alkalizing solutions containing potassium $(15 \mathrm{mEq}$. per liter) were administered intravenously. Although the patient was cachectic and weak, he did not appear critically ill, when he suddenly developed an aberrant ventricular rhythm and expired.

\section{DISCUSSION}

Cation exchange resins taken orally reduce the absorption of sodium from the intestine. When an amount of resin sufficient to neutralize 150 $\mathrm{mEq}$. of base was fed daily with a diet containing $100 \mathrm{mEq}$. of sodium (6 grams of salt), urinary excretion of sodium was reduced to $50 \mathrm{mEq}$. per day. Feeding $250 \mathrm{mEq}$. of resin with the same diet reduced daily urinary excretion of sodium to $8 \mathrm{mEq}$.

Salt restriction is, of course, important in the management of congestive heart failure. Its application, however, requires the patient to submit to the rigors of a selective diet. With the use of a cation exchange resin, the patient may satisfy his appetite within reasonable limits without absorbing excessive amounts of sodium. During periods of resin administration in two edematous patients 
with heart failure there was a diuresis of existing depots of fluid and edema failed to reaccumulate.

In the case of cirrhosis of the liver, use of the resin orally was also successful in preventing the absorption of sodium from the gut. Since the most important part of the treatment of cirrhosis is a dietary regime high in protein, and since devising a high protein, low salt diet is difficult, the use of resin might be an important addition to therapy of this condition.

Unfortunately, sodium is not the only ion, but is, in fact, the ion least likely to occupy the resin when in competition with potassium or calcium. From the balance study it did not appear that the subject lost more potassium than he consumed. There was, however, very low urinary excretion of potassium for 10 days after the resin was discontinued. In view of the gain in weight of $3.6 \mathrm{~kg}$. and the daily retention of 1.4 grams of nitrogen, during a period of low excretion of potassium and sodium it would appear that tissue and water were being replaced.

A calcium deficit would normally be anticipated from the in vitro observations, but did not occur in the balance study. The availability of calcium for absorption is closely related to the presence of insoluble complex acid radicals (i.e., oxalates, phytates) (29). The resin produces, in effect, a markedly acid diet which would increase the availability of the insoluble calcium for absorption (29). This may or may not be the explanation, but the fact remains that the subject did not develop a detectable calcium deficiency.

The secretion of sodium, potassium and calcium into the lumen of the gut and their subsequent reabsorption creates an active interchange of electrolytes across the gut wall. Of the ions to which the resin is exposed in its passage down the gut, the amount of sodium is by far in excess of potassium or calcium. Thus, a larger portion of the resin was occupied by sodium in vivo than was anticipated by the studies in vitro.

Consideration must also be given to cations other than sodium, potassium, and calcium; in particular, magnesium, iron, manganese, copper and cobalt. Prolonged feeding of exchange substances may well lead to a deficiency of one or another of these cations. Since basic organic ma- terials are also fixed to resin, these substances, too, must be considered. In the balance study, fecal nitrogen did not increase during resin feeding. It may be inferred from this fact that there were no excessive losses of amino acids in the stool. The losses of other basic organic substances (riboflavin, thiamin) were not measured. The magnitude of the problem of creating a deficiency as a result of the possible losses of these basic organic substances remains to be evaluated. The deficiency would depend greatly on the strength of the bond between the organic base and the particular exchanger. ${ }^{3}$

In exchange for cations, Liquonex CRW releases free hydrogen ion into the gut. Resin feeding is consequently equivalent not only to restricting salt intake but also to concommitantly administering 5-10 grams of ammonium chloride daily. With the usual administration of ammonium chloride, the kidney, in some measure, balances the anion excess with sodium and potassium. With the administration of resin, however, the availability of sodium and potassium for balance is small. In this instance, with the removal of sodium and potassium, ammonia production was forced to a maximum. It follows that administration of the resin to individuals with impaired renal function should be exercised with caution.

The disadvantage of oral administration of Liquonex CRW centered around the 20 to 25 size 00 capsules that had to be fed with each meal. Constipation may be experienced as the stool acquires the sandy consistency of the resin, but has so far only occurred in the subject of the balance study.

Evidence for calcium deficiency was lacking in this study but the possibility must still be considered. The evidence for potassium deficiency is stronger than for calcium and may well be a danger in the use of Liquonex CRW. Calcium and potassium occupy Liquonex CRW preferentially to sodium, an admirable characteristic for water softening for which the resin is primarily manufactured. This characteristic, however, is inherent in all cation exchange substances yet it does not

\footnotetext{
3 Patient C. G. has taken Liquonex CRW in daily dosage of $200 \mathrm{mEq}$. continuously for 10 months without clinical evidence of ill effects.
} 
seem to invalidate its use for removal of sodium from the diet.

The limited clinical material presented here illustrates the advantages and dangers of administration of Liquonex CRW. The evident dangers are acidosis and potassium deficiency. It is far from clear how the acidosis might have contributed to the death of the patient with cirrhosis of the liver, but there may have been some indirect relationship. Excessive loss of potassium must also be considered although the electrocardiogram did not exhibit the expected pattern of potassium deficiency. The use of potassium lactate, or potassium bicarbonate in conjunction with the resin may prove to obviate these dangers without reducing the efficacy of sodium removal. Liquonex CRW, although representing an exchanger with one of the higher capacities, is by no means the ideal substance. Exchange substances of still higher capacity, exchanging ions other than hydrogen, if effective at the $\mathrm{pH}$ and electrolyte concentration of the intestine, would represent further advances in resin therapy.

\section{CONCLUSIONS}

1. The principle of the use of a cation exchange substance has been shown to be sound in retaining dietary sodium in the gastrointestinal tract to be excreted in the stool.

2. Its use in congestive heart failure and cirrhosis of the liver resulted in a diuresis of existing depots of fluid which did not reaccumulate while the resin was administered.

3. The undesirable characteristics of a particular exchange substance are indicated. With the use of Liquonex CRW, potassium depletion and acidosis must be considered as possible hazards.

\section{BIBLIOGRAPHY}

1. The Greek Herbal of Dioscorides, Bk. V, Section 113, p. 628 : Lemnia Ge (translated by John Goodyear). Robert A. Gunther, Ed., Oxford U. Press, London, 1934.

2. Thompson, C. J. S., Terra Sigillata, a famous medicament of ancient times. Proc. 17th Internat. Cong. Med., 1914, 23, 433.

3. Boyd, G. E., Schubert, J., and Adamson, A. W., Exchange adsorption of ions from aqueous solutions by organic zeolites. I. Ion-exchange equilibria. J. Am. Chem. Soc., 1947, 69, 2818.
4. Bauman, W. C., and Eichhorn, J., Fundamental properties of a synthetic cation exchange resin. J. Am. Chem. Soc., 1947, 69, 2830.

5. Boyd, G. E., Adamson, A. W., and Meyers, L. S., Jr., The exchange adsorption of ions from aqueous solutions by organic zeolites. II. Kinetics. J. Am. Chem. Soc., 1947, 69, 2836.

6. Applezweig, N., Ion exchange absorbents as laboratory tools. Ann. N. Y. Acad. Sci., 1948, 46, 295.

7. Way, J. T., On the power of soils to absorb manure. J. Roy. Agr. Soc. Eng., 1850, 11, 313 ; Ibid., 1852, 13, 123.

8. Walton, H. F., Ion exchange between solids and solutions. J. of Franklin Institute, 1941, 232, 305.

9. Tompkins, E. R., Laboratory applications of ion exchange techniques. U. S. Atomic Energy Commission, Isotopes Division Circular C-10, 1948.

10. Jenny, H., Kationen und anionenumtausch an Permutit grenzflächen. Kolloidchem. Beihefte, 1927, 23, 428.

11. Mattson, S., The electrokinetic and chemical behavior of aluminosilicates. Soil Science, 1928, 25, 289.

12. Wiegner, G., Some physico-chemical properties of clays. I. Base exchange or ionic exchange. J. Soc. Chem. Ind., 1931, 50, 65T.

13. Vanselow, A. P., E'quilibria of the base-exchange reactions of bentonites, permutites, soil colloids, and zeolites. Soil Science, 1932, 33, 95.

14. Walton, H. F., Equilibria in a carbonaceous cation exchanger. J. Phys. Chem., 1943, 47, 371.

15. Adams, B. A., and Holmes, E. L., Absorptive properties of synthetic resins. I. J. Soc. Chem. Ind., $1935,54,1 \mathrm{~T}$.

16a. Segal, H. L., Hodge, H. C., Watson, J. S., Jr., and Scott, W. J. M., A polyamine formaldehyde resin. I. Its effect upon $\mathrm{pH}$ of acidified solutions and $\mathrm{pH}$ and pepsin of gastric juice in vitro. II. Its toxicity in rats: preliminary feeding tests. Gastroenterology, 1945, 4, 484.

b. Segal, H. L., Hodge, H. C., Watson, J. S., Jr., and Coates, H., A polyamine formaldehyde resin. III. Chronic toxicity experiment in rats. Gastroenterology, 1947, 8, 315.

17. Martin, G. J., and Wilkinson, J., The neutralization of gastric acidity with anion exchange resins. Gastroenterology, 1946, 6, 315.

18. Spears, M. M., and Pfeiffer, M. C. J., Anion exchange resin and peptic ulcer pain. Gastroenterology, 1947, 8, 191.

19, Dock, William, Sodium depletion as a therapeutic procedure: the value of ion-exchange resins in withdrawing sodium from the body. Tr. A. Am. Physicians, 1946, 59, 282.

20. Barnes, B., Richardson, D., Berry, J. W., and Hood, R. L., Flame photometry, a rapid analytical procedure. Indust. \& Engin. Chem. (Analytical Edition), 1945, 17, 605 . 
21. Wilson, D. W., and Ball, E. G., A study of the estimation of chloride in blood and serum. J. Biol. Chem., 1928, 79, 221.

22. Fiske, C. H., and Subbarow, Y., The colorimetric determination of phosphorus. J. Biol. Chem., 1925, 66, 375.

23. Hawk, P. B., Oser, B. L., and Summerson, W. H., Practical Physiological Chemistry. Blakiston Co., Philadelphia, 1947, Ed. 12, p. 828.

24. Folin, O., and Wu, H., A system of blood analysis. J. Biol. Chem., 1919, 38, 81.
25. Sussman, S. Personal Communication.

26. King, E. J., and Armstrong, A. R., A convenient method for determining serum and bile phosphatase activity. Canad. M. A. J., 1934, 31, 376.

27. Kunin, R., Ion exchange. Analyt. Chem. 1949, 21, 87.

28. Gamble, J. L., Chemical anatomy, physiology and pathology of extracellular fluid. Harvard University Press, Cambridge, Mass., 1947, Chart 5-b.

29. Logan, M. A., Recent advances in the chemistry of calcification. Physiol. Rev., 1940, $20,522$. 